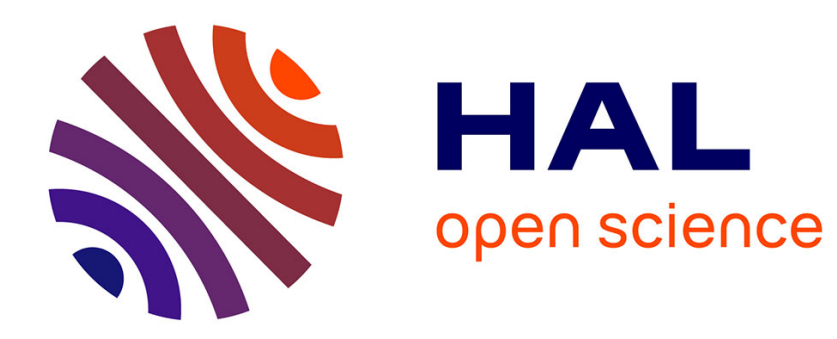

\title{
The role of scientific committees within Regional Fishing Commissions
}

Sophie Gambardella

\section{To cite this version:}

Sophie Gambardella. The role of scientific committees within Regional Fishing Commissions. The Finnish yearbook of international law, 2009, 20, pp. 373-390. hal-01447098

\section{HAL Id: hal-01447098 \\ https://hal.science/hal-01447098}

Submitted on 3 Feb 2020

HAL is a multi-disciplinary open access archive for the deposit and dissemination of scientific research documents, whether they are published or not. The documents may come from teaching and research institutions in France or abroad, or from public or private research centers.
L'archive ouverte pluridisciplinaire HAL, est destinée au dépôt et à la diffusion de documents scientifiques de niveau recherche, publiés ou non, émanant des établissements d'enseignement et de recherche français ou étrangers, des laboratoires publics ou privés. 


\title{
THE ROLE OF SCIENTIFIC COMMITTEES WITHIN REGIONAL FISHING COMMISSIONS
}

By

\author{
Sophie Gambardella*
}

\begin{abstract}
The omnipresence of science in environmental protection has led law-makers to consult experts. In terms of management and conservation of fisheries, this interaction between science and law has been institutionalized within Regional Fishing Commissions through the creation of permanent scientific committees. These committees are made up of experts and give advice to Commissions, who use it to set up the rules which regulate management decisions. Although at first sight the scopes of respective roles seem strictly defined, one can note, particularly through the case of the International Commission for the Conservation of Atlantic Tuna, that more than an interaction we are may be witnessing a mixup between science and law.
\end{abstract}

\footnotetext{
* Teaching Assistant, Centre d'Etudes et de Recherches Internationales et Communautaires (CERIC - CNRS UMR 6201), Faculty of law and political science, University Paul Cézanne Aix-Marseille III.
} 
It is a traditional assumption that international law deals with relations; it regulates social facts in order to ease tensions which could arise from states over-exercising their sovereignty. From this point of view, international law is thus constructed inductively; it comprehends social needs and offers the sought-after norm, which is, by nature, a social norm.

In 1972, during the Stockholm summit, this approach of the creation of international law was shaken at two levels. International law, which was almost exclusively seen as a law of relationships, also became a law of phenomena - these phenomena being originally rooted in natural causes but then modified or even turned upside down by human activities. In such a situation, the development of international rules requires not only that their makers understand a given natural phenomenon but also the impacts human activities have on this phenomenon. Law-makers have to turn to competent people who are able to provide the knowledge needed to make a decision on the appropriate legal rule. In other words, law-makers turn to experts, defined 'in legal terms (...) as persons mandated in the framework of an expertise, that is to say a procedure aiming to enlighten an authority which has to make a decision'. ${ }^{1}$ The need to seek expert advice is all the more unavoidable as Principle 2 of the Stockholm Declaration ${ }^{2}$ leads to complement the inductive rule creation method with a prospective method which will give the rule two additional dimensions, one preventive and one curative.

Thus, in the field of international law, besides rules of a purely social nature, other rules appear which aim at meeting social needs but are grounded in scientific knowledge. These hybrid rules are often described as 'socio-technical' ${ }^{3}$ when they contain specific technical requirements. More generally, they could be described as 'socio-scientific' rules when they are based on scientific expertise but do not necessarily contain any technical data.

Socio-scientific rules today run throughout the whole of the fields covered by international environmental law: climate change, biodiversity protection, biotech products etc., and their drafting is grounded in the recourse to experts. The issue of the role experts had in the making of the law which aims at regulating the management of these phenomena has been the object of extensive literature with regard to climate change ${ }^{4}$ and biotechnological products. ${ }^{5}$ Yet, as regards biodiversity, studies on this topic are scarcer. Still, numerous decisions on the rules which are necessary to enhance biodiversity conservation cannot be made without scientific data. Concerning the conservation of fisheries for example, it would

\footnotetext{
1 'au sens juridique (...) comme la personne désignée dans le cadre d'une expertise, c'est-à-dire d'une procédure destinée à éclairer une autorité chargée de prendre une décision': Raphäl Encinas de Munagorri, 'Quel statut pour l'expert?' 103, Revue française d'administration publique (2002) 379-389, at 379. All translations are the author's. This definition of expertise is commonly accepted by all the authors who deal with the issue, whether they are legal experts or sociologists.

2 'The natural resources of the earth, including the air, water, land, flora and fauna and especially representative samples of natural ecosystems, must be safeguarded for the benefit of present and future generations through careful planning or management, as appropriate'.

${ }^{3}$ Michel Callon \& Arie Rip, 'Humains, non-humains: morale d'une coexistence', in Jacques Theys \& Bernard Kalaora, La Terre outragée: les experts sont formels! (Paris, Editions Autrement, 1992), 140-156.

${ }^{4}$. For a full study of this question, see Raphaël Encinas de Munagorri, Expertise et gouvernance du changement climatique (Paris, LGDJ, 2009), 1-239.

${ }^{5}$. In the WTO special group's report in the European Communities-Measures affecting the approval and Marketing of biotech products case, an incredible number of experts was involved and the question of the role of experts arose from this very complex dispute. For a comment, see the special issue of the Revue européenne de droit de l'environnement, 'Dossier spécial: le différend Communautés européennes-produits biotechnologiques tranchés à l'OMC' edited by Marie-Pierre Lanfranchi, 2, REDE, (2008), 127-170.
} 
be unthinkable to set fishing quotas for certain species randomly. Science, in this domain, will be the foundation of law-making.

In view of this observation, numerous Regional Fishing Commissions have established scientific committees which were integrated into their structure. Amongst these numerous commissions, one of them deserves special attention because of its particular ratione materiae competence, the conservation of tunas.

In 2008, the editorial of an issue of the 'Courrier de la Planète' dedicated to biodiversity drew attention with its alarming title: 'Red Alert on Tuna!' The increasing difficulties of replenishing this stock which is overfished due to its high market value were once again emphasized. In its conclusion, the editorial pointed an accusing finger at the international management of this resource, describing it as 'a real textbook case of environmental governance mess'. ${ }^{6}$ However, since the $1970 \mathrm{~s}$, efforts have been made to manage this stock and the fears of seeing it disappear played a large part in the 1966 creation of the International Commission for the Conservation of Atlantic Tunas (ICCAT). ${ }^{7}$ The first tuna organization, the Inter American Tropical Tuna Commission (IATTC) created in 1949, only covered the Asia-Pacific region, and the Atlantic region had no particular structure to manage this stock until the ICCAT was created. The ICCAT covers not only the whole of the Atlantic Ocean but also adjacent seas.

The ICCAT quickly stood out from all other tuna organizations because it wasn't in competition with any other regional fishing organization ${ }^{8}$ and because it focused on red tuna, an emblematic species. When the ICCAT was created, the writers of the Convention were already aware of some of the challenges of tuna management; everyone knew that without the relevant scientific data, law-making and decision-making would be at best inefficient, and at worst counter-productive. The creation of the Commission then came with the creation of a Standing Committee on Research and Statistics (SCRS) to scientifically support the Commission. Before the ICCAT was created, some data on Atlantic tuna had been gathered by a specialized working group from the International Council for the Exploration of the Sea. Yet this group merely gathered data, which means that no global assessment of the stock had been carried out. The SCRS was intended to compensate for this lack of scientific data by carrying out stock assessments of different tunas in the Atlantic Ocean and adjacent seas, and by recommending measures the Commission should adopt in order to ensure the sustainable management of tuna fisheries stock. These two bodies are thus working in the same direction and within the same framework, in order to set up socio-technical rules which aim at reaching a balance between ecological stakes and economic needs. In temporal terms, one step should logically follow the other: science first, then law-making. However, the hybrid nature of the result of such process (the socio-technical rule) leads jurists to consider this linear approach with caution. By nature, the hybrid rule suggests an intersection between these two areas in which reciprocal influences between science and law can be anticipated. Questions deepen

\footnotetext{
6 'Un véritable cas d'école en matière d'imbroglio de gouvernance environnementale': 86, Courrier de la planète, (April-June 2008), at 1: This issue was based on a conference organised by IDDRI (Institute for Sustainable Development and International Relations) on the 20th and 21st of March 2008 in Monaco, entitled 'Towards a new governance of biodiversity on the open sea'.

${ }^{7}$ The Rio de Janeiro convention, founding agreement of the ICCAT, was adopted in May 1966. It was ratified by seven states and entered into force on the 21 st of March 1969.

${ }^{8}$ The ICCAT could have overlaped the scope of the General Fisheries Council for the Mediterranean (GFCM) but cooperation between the two organizations was set up, giving the ICCAT a quasi monopoly on tuna-related rules.
} 
and answers become more confused when contemplating the respective parts of science, law and their interactions in the drafting of socio-technical rules.

Another distinction comes fully into play when one attempts to measure the interactions between science and law. An individual, who is an expert in his/her field and is qualified with regard to a particular question, does not necessarily become an expert in the legal meaning of the term. ${ }^{9}$ This suggests that the expert, that is to say the person entitled to bring specific knowledge to law-makers, does not fulfil the same role. Indeed, a scientist, whose work consists in conducting research in order to elaborate scientific theories or statements, will find himself playing another role when mandated as an expert. The integration of SCRS scientists within the ICCAT structure could in this view change the nature of their work, due to the fact that science would be absorbed in the law-making process whirlpool. According to some, 'the knowledge elaborated in these circumstances does not have the status of scientific knowledge'. ${ }^{10}$ Without adopting such a purist view of science, ${ }^{11}$ an observation of the functioning of the SCRS leads us to concede that scientific statements are somewhat transformed within the ICCAT.

From another point of view, one could also point at the fact that without the experts' scientific statements, decision-makers would lack arguments to justify the often unpopular legal obligations they impose in order to protect the environment. How could one convey to fishermen that they must reduce their yield and therefore their income without being backed up by scientific statements to explain that, in the long term, stocks will run out if the fishery efforts are not reduced? Similarly, at a higher level, how could one convince states to accept being bound by ICCAT recommendations imposing fishing quotas when not only will these quotas be detrimental to their economy in the short term, but also the implementation of these measures at a national level will create inevitable social tension? When adopting international and domestic measures, emphasis put on the fact that socio-technical rules are justified on a scientific basis can help to abort all tensions and reluctances, which could be generated by environmental protection rules which reduce the primacy of economy over ecology.

\section{IS SCIENTIFIC KNOWLEDGE DENATURED BY THE LAW-MAKING PROCESS?}

It is commonly accepted that science is the systematic study of the structure and behaviour of the physical world, especially by watching, measuring and doing experiments and the development of theories to describe the results of these activities'. ${ }^{12}$ This definition reveals several characteristic features of scientific statements. Science results from an observation of facts and deductions derived from these observations. In addition, before any scientific statement is reached, experimental verifications must be carried out. What is the aim of this verification? It is to ensure that the scientific statement is objective, in the sense that what is expected of a scientific statement is a reflection of findings and not of what the scientist would have liked to find. Within the ICCAT, the SCRS should then produce objective scientific statements on the state of stocks, on the basis of which the Commission could base its decision to adopt appropriate rules. However, the observation of the SCRS structure leaves doubts as to the objectivity of their scientific statements.

\footnotetext{
${ }^{9}$ See the above definition.

10 'la connaissance élaborée n'a [alors] pas le statut de la connaissance scientifique’: Philippe Roqueplo, Entre savoir et décision, l'expertise scientifique (Paris, INRA, 1997), at 16.

${ }^{11}$ It is, one must admit, easier not to have such a vision of a particular field when it is not one's own.

${ }^{12}$ Definition from the Cambridge Advanced Learner's Dictionary.
} 
In addition, recourse to 'exact' science to produce socio-technical rules could, because of its name, be misleading. Obviously, this type of science is not 'exact' ad vitam eternam; it is called 'exact' at the precise moment it is produced, which is to say, based on the knowledge available at that time. What is more, the fact that some scientific statements are grounded in 'exact' sciences does not mean that they are without uncertainties, quite to the contrary, as uncertainty is inherent to science and is its very raison d'être. And yet, 'in environmental law, we are witnessing an instrumentalisation of the law aiming at hiding scientific uncertainties', ${ }^{13}$ and this hiding occurs within the ICCAT even before the diplomatic body negotiations come into play.

\subsection{Framing the objectivity of scientific statements in jure}

Observing the structure of the SCRS to determine the degree of objectivity of the scientific statements it produces implies to adopt a global vision of its functioning with a special attention to its setting up, budget, and terms of office. Unsurprisingly, the SCRS is made up of distinguished scientists in their field, but more than their national positions, it is their status within the SCRS which is of prime importance in this analysis. The functioning of the SCRS allows for the intervention of two types of scientists: one type works as a representative of their state; another type work mostly as observers, individually or within the framework of an NGO. ${ }^{14}$ Experts appointed by member states work within the ICCAT on the basis of data supplied by their state. During the SCRS inter-sessions, scientists who do not belong to the ICCAT and observers can submit scientific reports on specific issues through the ICCAT Secretariat. For both categories of experts, scientific reports will be discussed during the plenary meetings of the Committee ${ }^{15}$ in order to determine the scientific statement which will be transmitted to the Commission. Seen in this light, the composition and functioning of the SCRS does raise questions as to the objectivity of the expertise it provides.

Traditionally, experts are expected to be impartial and independent so as to be able to deliver objective scientific statements. Studies dealing with a possible international status for experts endeavour to find ways to guarantee such independence and impartiality. ${ }^{16}$ In terms of jurisdictional expertise, ${ }^{17}$ experts' independence and impartiality are quite often only 'guaranteed' by the fact that experts take an oath in front of the tribunal, which sometimes leads to improbable situations. Such was the case in the Case concerning Land Reclamation by Singapore in and around the Straits of Johor, brought before the International Tribunal for the Law of the Sea (ITLOS). The expert appointed by Malaysia worked first as the main technical advisor for Malaysia before taking an oath in order to allow the Tribunal to question

\footnotetext{
${ }^{13}$ Michel Prieur, 'Incertitude juridique, incertitude scientifique et protection de l'environnement', in Incertitude juridique, Incertitude scientifique, Acts from the seminar of 1'Institut Fédératif 'Environnement and Water' held in Limoges, France, on the 5th of April 2000 (Limoges, PULIM, 2001), 9-16, at 14.

${ }^{14}$ The Commission adopted the citeria related to the observer status in its Decision [05-01] of the Commission, adopted at its 11th Special Meeting held St James of Compostela, Spain, 16-23 November 1998 and amended at its $19^{\text {th }}$ Regular Meeting, Sevilla, Spain, 14-20 November 2005.

${ }^{15}$ The SCRS holds annual meetings. Since 1987, the SCRS and the commission meetings have been held separately, the SCRS meetings taking place one month before the Commission's to give the Commission sufficient time to read the SCRS report.

${ }^{16}$ Encinas de Munagorri, 'Quel statut pour 1'expert?', supra note 1, 379-389.

${ }^{17}$ On the relationship between judges and experts, see Olivier Leclerc, Le juge et l'expert: Contribution à l'étude des rapports entre le droit et la science (Paris, LGDJ, 2005), 1-471.
} 
him as 'an expert'. His independence and impartiality were, in this case, more than questionable. $^{18}$

Some authors have gone so far as to wonder whether experts' independence and impartiality in law-making or decision-making processes was, in the end, desirable on the international scene. ${ }^{19}$ In their view, 'objective' scientific statements may lessen the role of consensus between states in law-making. Furthermore, the regulation of environmental protection often consists in finding a fair yet fragile balance between nature preservation and economic development, which allows for the adoption of the socio-technical rules states can endorse. A purely scientific statement is not supposed to take economic aspects into account at all and there is thus a risk that this would make states wary, or even reluctant. According to this reasoning, recourse to experts appointed by states - who are necessarily influenced, at least unintentionally, by their national priorities and difficulties - seems, viewed from this angle, much more acceptable than the creation of a body of international independent experts in charge of delivering international ideally 'objective' science. The International Law Commission indeed noted in 1973 that its success was partly due to 'the continuing interaction (...) between scientific expertise and the governments' responsibilities, between independent thought and the realities of international life'. ${ }^{20}$

The SCRS, because of its composition, also constantly confronts observers' independent thought with the reality of international life conveyed by the experts representing their states. During a first stage, scientific experts write their reports and give these to the SCRS plenary session. Then comes a second stage of debate and transparency or at least, of something near the democratization of expertise. Interestingly, this model comes close to the balance between the confidentiality and the publicity of expertise which Philippe Roqueplo recommended. ${ }^{21}$ The objectivity of scientific statements must thus be seen as a relative notion, for almost from the start scientific statements are tinged with political realism. The integration of science within the law-making process thus leads to move away from the idea of 'pure' science and to admit the existence of politically reasonable, or at least acceptable, scientific statements on which socio-technical rules can be built. The fact that scientific statements are distorted by the necessities of the law-making process is amplified in the framework of the ICCAT by the means given to the SCRS to fulfil its mission: the SCRS budget is indeed an integral part of the general budget of the Commission.

If in 1998 it was not difficult to obtain a consensus among the 23 member states on the budget to be adopted, nowadays, the number of ICCAT member states has nearly doubled and the ranks were joined by small states which lack the means which would be necessary to increase the ICCAT general budget. Nevertheless, non-budgetary funds made up of voluntary contributions from some states were set up to allow scientists from developing countries not only to attend SCRS meetings but also to benefit from trainings in order to involve them efficiently in the expertise process. For the time being, as the SCRS budget depends on the political will of the states, these can choose what they want to finance, a situation which,

\footnotetext{
${ }^{18}$ Case concerning Land Reclamation by Singapore in and around the Straits of Johor (Malaysia v. Singapore), ITLOS/PV.03/01, at 18 .

${ }^{19}$ Yves Daudet, 'Les membres des commissions d'experts', in French Society for International Law, Les agents internationaux, Acts from the Symposium of the FSIL held in Aix en Provence, 24-26 May 1984 (Paris, Pedone, 1985), 93-107, at 96-101.

${ }^{20}$ Report of the International Law Commission on the work of its twenty-fifth session, 7 May-13 July 1973 , A/9010/Rev.1, at para. 166.

${ }^{21}$ Roqueplo, Entre savoir et décision, l'expertise scientifique, supra note 9, at 57-61.
} 
without having a direct impact on the objectivity of expertise, is still another way of framing it politically. Thus, the diplomatic body keeps a permanent eye on what will constitute the basis of the socio-technical rules elaborated within the ICCAT. The functioning of the SCRS does have an influence on expertise, even before it is conducted. Nevertheless, the objectivity of its scientific statements is not completely annihilated, since the SCRS is free to choose the subject of its research.

Experts whose work is intended to be used in a decision-making process are in a relationship in which the one who commissioned the expertise determines its object. The work carried out by the $\mathrm{SCRS}^{23}$ thus meets the requests of the Commission, issued in recommendations and/or resolutions, or even its own recommendations. These recommendations and/or resolutions of the Commission are very generic and use wording like '[i]n the year 2009, and thereafter every three years, the SCRS shall conduct a stock assessment and provide advice relative to paragraphs 2 and 3' or ' $\mathrm{t}$ ] he Commission requests that SCRS carry out an evaluation of the fishing capacity of the different fleets /vessels that participate in this fishery with a view to establishing the corresponding fishing efforts' ${ }^{24}$ The content is thus not conditioned by the requests from the Commission since it only requires from the Committee an obligation of results and the Committee's scope for action is complete with regard to the means. Moreover, nothing, if not its budget, prevents the Committee from acting ultra petita, as it made the point of stating in its latest report: 'that although the Commission does not systematically request assessments (or accepts when these have been proposed by the SCRS), the Committee considers that it is their responsibility to carry out a regular follow-up (as far as possible, annually) of the fisheries' development and proceed, routinely, to carry out necessary analysis to formulate advice on the most recent state of the stocks that are under its mandate'. ${ }^{25}$ Without exceeding the Commission's assigned objectives, the Committee can in this way carry out regular scientific work, far from sporadic political moods and the pressure they can create. Scientific statements issued by the SCRS will thus be relatively objective, but sufficiently so for allowing to consider them to be scientific statements.

The legal framework surrounding the SCRS undoubtedly conditions the scientific statements produced. When expertise enters the realm of law and decision-making, it is immediately caught up in political stakes so that interaction and blurring between science and law exists ab initio in the drafting of socio-technical rules, and these rules can even end up getting drafted within the scientific body.

${ }^{23}$ The SCRS includes:

- Sub-Committees: Sub-Committee on Statistics and Sub-Committee on Ecosystems;

- Species groups: tropical tunas, albacore, bluefin tuna, billfishes, swordfish, sharks, small tunas, southern bluefin tunas;

- Other working groups: Stock assessment methods working group, ad hoc working group on coordination of tagging information;

- Special research programs: Enhanced Billfish Research Program, bluefin Year Program (BYP).

Emphasis in this contribution is put on the stock assessment group, the other groups mainly working on improving scientific research techniques, which does not lead to drawing up socio-technical rules.

${ }^{24}$ 'Recommendation by ICCAT concerning the limitation of fishing capacity on northern albacore', Recommendation [98-08], entered into force on the 21th of June 1999, at para 7.

Available at: <http://www.iccat.int/Documents/Recs/ACT_COMP_2008_ENG.pdf> (visited 24 November 2009).

${ }^{25}$ Report of the Standing Committee on Research and Statistics (SCRS), Madrid, Spain, 29 September-3 October, 2008, at 188. Available at: <http://www.iccat.int/Documents/BienRep/REP_EN_08-09_I_2.pdf $>$ (visited 24 November 2009). 


\subsection{The de facto erasing of the plurality of truths}

In practice, the making of scientific statements happens in two stages: the first stage is confidential, the second one public. During the confidential stage, scientific documents which will be discussed during the second stage are drawn up. Some points that are of interest in the analysis of the interactions between science and law deserve to be developed further.

The role of scientific data is undeniable in the carrying out of an expertise, even more so when the subject is as elusive as a state-of-the-stock assessment. The quality and quantity of the available data will determine the degree of uncertainty in the final scientific statement. Thus, extensive scientific data will allow reducing the number of initial assumptions and the number of hypotheses about the situation in conclusion. Data gathering represents the Achilles tendon of the system. When the SCRS started working, only Japan had a statistics system that enabled the gathering of reliable data on tuna catches; the other states had only partial information about their catch. Furthermore, the data often stayed at a national level which made it difficult for the scientists to collect and analyse it, thus forcing them to multiply initial assumptions to carry out their expertise. ${ }^{26}$ Even if, with time, many states established efficient statistic systems, the problem of data collection still remains at the heart of the debate. Today, states do have all the data needed by scientists but they often falsify the results to avoid being put in the dock. In fact, the quotas imposed on the states lead them not to declare excessive catches and the scientists then get underestimated figures. They must then speculate on the existing gap between state declarations and actual catches. ${ }^{27}$ This problem could be solved if the SCRS had the means to collect data with scientific vessels and if it were no longer obliged to rely on the states. In the current state of the system, the scientists working in the SCRS are forced to multiply their assumptions to cover all the uncertainties reinforced by the lack of accurate scientific data. In the end, the result cannot be one scientific statement but a range of scientific statements. And yet, these scientific statements will become the scientific basis for estimates of the impact of catches on future fish stocks elaborated by scientists specialized in population dynamics.

Population dynamics can be defined as "the field which endeavours to explain and forecast the impact of fishing upon halieutic resources through modelization. Objectively and from its first studies, it aims at supporting decision-making in fishery management'. ${ }^{28}$ This field is a branch of quantitative biology which 'has been, if not the sole source, then the most important source of expertise in fishing management'. ${ }^{29}$ On this point, the SCRS is not an

\footnotetext{
${ }^{26}$ Alain Fonteneau, 'Scientific and historical summary of ICCAT: Rio de Janeiro 1966-Dubrovnik 2006', in ICCAT, Contributions to the Commemorative sessions of the 40th Anniversary of ICCAT held during the 2006 SCRS and Commission meetings, at 10.

Available at: < http://www.iccat.int/Documents/Other/PUB_40_ANNIVERSARY.pdf> (visited 24 November 2009).

${ }^{27}$ This problem is particularly acute concerning the East Atlantic and Mediterranean bluefin tuna. The economic and social stakes surrounding this species have led states to provide underestimated catches figures -or no information at all.

28 'la discipline qui vise à expliquer et prédire l'effet des pêches sur les ressources halieutiques par la modélisation. Elle se situe sans ambigü̈té, et dès les premiers travaux, comme une aide à la décision pour la gestion des pêches': Gérard Biais, 'Progrès scientifique et gestion des pêches', in Jean-Pierre Beurier, Alexandre Kiss \& Said Mahmoudi eds., New technologies and law of the marine environment (The Hague/London/Boston, Kluwer law international, 2000), 3-21, at 6.

29 ' $a$ été, et reste la source d'expertise majeure sinon souvent exclusive en gestion des pêches': Ibid., at 10.
} 
exception to the rule, but it has encountered some difficulties in its implementation. Global models of stock dynamics representation use two types of data: fishing effort and rate of catch. The low degree of reliability of the data available to the SCRS can distort the modelization or force the scientists once again to multiply hypotheses. Moreover, the SCRS still uses Maximum Sustainable Yield (MSY) as a reference for numerous overexploited species, although the fishing mortality rate has been found a more relevant criterion - still insufficient - both within the ICCAT $^{30}$ and by the doctrine. ${ }^{31}$ Diversified precautionary reference points depending on the state of the stock would best offer most the needed perspectives for stock management; this solution was indeed recommended by the 1995 United Nations Agreement on straddling stocks. Faced with these obstacles in the making of undisputable scientific statements, SCRS scientists have to resort to the production of plural truths, each one being accompanied by a vector of occurrence probability. Given the situation, this plurality of truths in scientific knowledge can be seen as the guarantor of the reliability of scientific statements, considering that ' $[\mathrm{t}] \mathrm{he}$ time of single truths, the pride and joy of the age of the Enlightenment, hopelessly devoted to the cult of the Goddess Reason, has been replaced by a time of doubting and uncertainty, a time of unverifiable hypotheses and plural truths, a more modest and more realistic attitude that hard and so-called "exact" sciences have had to accept'. ${ }^{32}$ The linear expertise system could then be brought back to the fore, with experts producing scientific statements which offer a plurality of truths and law-makers would come to a decision among these scientific statements in order to draw up the needed sociotechnical rule. This view of expertise, which confines everyone to his own sphere, isn't however advisable in the field of biodiversity protection: 'experience has largely shown that open advice, which puts forward assessment uncertainties, generally leads to the option that is politically most easy to get accepted, and thus the least restrictive for fishing in the short term'. ${ }^{33}$

Reading through the SCRS reports, one can see that the Commitee tried to avoid making this mistake. Indeed, in 2008, when the Committee states in its report, on the one hand, that the objectives of the Convention concerning yellowfin tuna have been achieved and, on the other hand, that there is still a $60 \%$ probability that the state of the stock do not meet the Convention's objectives, it still recommends one single approach to the Commission: if the Commission wishes to increase long term sustainable production, it must not increase the fishing effort and must take efficient measures to reduce the baby yellowfin tunas mortality through fishing. The self-confessed uncertainty on the part of the SCRS with

\footnotetext{
${ }^{30}$ Report of the Independent Performance Review of ICCAT, Madrid, 2009, at 38.

Available at: < http://www.iccat.int/Documents/Other/PERFORM_\%20REV_TRI_LINGUAL.pdf $>$ (visited 24 November 2009)

${ }^{31}$ For an explanation of the stakes of population dynamics, please see Biais, 'Progrès scientifique et gestion des pêches', supra note 27, 3-21.

32 'au temps des vérités uniques, fierté d'un siècle des Lumières, confit en dévotion devant la déesse Raison, a succédé le temps du doute et de l'incertitude, celui des hypothèses invérifiables et des vérités plurielles, attitude plus modeste et réaliste, que les sciences dures et dites exactes ont du admettre', Jacqueline Morand-Deviller, 'Le "système expert": expertise scientifique et gestion de l'environnement', in Etudes offertes à Jacques Dupichot (Bruxelles, Bruylant, 2004), 359-375, at 361.

33 'l'expérience a largement démontré qu'un avis ouvert, mettant en avant l'incertitude des évaluations, conduit généralement au choix de l'option politiquement la plus facile à faire accepter, et donc la moins restrictive pour la pêche à court term': Biais, 'Progrès scientifique et gestion des pêches', supra note 27, at 15.
} 
regard to its assessments is not echoed by its recommendations to the Commission. ${ }^{34}$ Why don't they reflect the plural voices of scientific expertise? What could seem a trivial incident but was felt like an intrusion by the ICCAT scientists may provide a few answers.

Until 1981, the scientists were divided on the question of whether the bluefin tuna stock was split into two stocks or whether they were dealing with a single stock. This uncertainty made it compulsory to take into account the two hypotheses in their models. In 1981, the Commission adopted the hypothesis of two independent stocks and imposed this vision on the SCRS, which since then bases its assessments on this assumption. The Commission thus forced the SCRS to leave aside the plurality of truths and drove it to adopt a peremptory approach. The Commission's behaviour can easily be explained from a political point of view. It is obvious that on such a delicate issue as bluefin tuna management, the Commission wanted to be able to rely on what appeared to be consistent scientific knowledge in which no doubt subsisted and which would give no ground to question its decisions.

The edges of the scientific knowledge are thus smoothed by the law and decisionmaking system and its imperatives. 'Experts then do not convey absolute rationality but rather a point of view relative to the state of knowledge in their field and the context'. ${ }^{35}$ Experts exceed their role as scientists in order to make judgements, which are admittedly derived from their knowledge but which come more within the role of decision-makers than that of a mere 'bringer of knowledge'. They make decisions and therefore play an active role in the creation of the socio-technical rule. They no longer merely bring knowledge; they make this knowledge operational. 'In fact, experts themselves assure that what they produce cannot be labelled as science in the ordinary sense of the word, but a hybrid activity which combines scientific elements with a dose of social and political judgement ${ }^{36}$ What consequences such a hybridization at what is supposed to be the scientific stage have on the competence on lawmakers?

\section{THE LEGITIMIZATION OF LAW BY SCIENTIFIC KNOWLEDGE}

The linear system of assessment is not totally shaken up by the intrusion of science into law-making. Though it is clear that this linearity is not absolute, there are still two distinct stages following each other in time with an intervention by the law/decision-making body at the second stage. International law remains founded on state will, which means that the state still has the last word when it comes to drawing up its commitments. The implementation of socio-technical rules did not reduce the principle of state sovereignty. Indeed, states decide on the object and extent of their commitments.

\footnotetext{
34 Report of the SCRS, Madrid, Spain, 29 September - 3 October 2008, 45-58. Available at: $<$ http://www.iccat.int/Documents/BienRep/REP_EN_08-09_I_2.pdf > (visited 24 November 2009).

35 'L'expert n'est donc pas porteur d'une rationalité absolue mais d'un point de vue relatif à l'état des connaissances dans sa discipline et au contexte': Biais, 'Progrès scientifique et gestion des pêches', supra note 27 , at 15 .

36 'En fait, les experts eux-mêmes assurent que ce qu'ils produisent ne saurait être désigné comme de la science dans le sens ordinaire, mais une activité hybride qui combine les éléments scientifiques avec une certaine dose de jugement social et politique': Eric Naim-Gesbert, Les dimensions scientifiques du droit de l'environnement (Bruxelles, Bruylant, 1999), at 642.
} 
However, the intervention of scientific expertise in the law-making process disrupted the classic pattern of creation of international law. Scientific knowledge brought to lawmaking bodies is altered to the point where scientists have already made choices among all the knowledge available and have already guided the decision. Even if their role 'is preliminary and not decisional', ${ }^{37}$ scientific expertise nevertheless seems to act as a first stage of negotiation in the drafting of socio-technical rules.

\subsection{Knowledge-shopping and the diplomatic body}

The reading of the SCRS reports could lead to the idea that the role of the Commission is restricted to the approval of the recommendations set by the Committee. The SCRS has already chosen between different hypotheses and decided which ones seemed most reasonable. Socio-technical rules would thus be already drawn up and all that would be left would be to give them a legal form and nature. However, the Committee's opinion is merely advisory, the Commission is not bound by its advice and keeps its freedom to adopt or reject the recommendations the Committee puts forward. ${ }^{38}$ Going into detail of the achievements of the ICCAT management of tuna fisheries, it is obvious that political choices come to paralyze or at least guide the protection of certain species amongst the target species. ${ }^{39}$ The 2009 Report of the Independent Performance Review of the ICCAT states that not only has the organization reached its targets for only four stocks (bigeye tuna, swordfish in the North Atlantic, swordfish in the South Atlantic and yellowfin tuna), but also that it is impossible to assess whether the ICCAT objectives were reached for three other stocks (albacore in the Mediterranean, sailfish and shikpjack tuna) ${ }^{40}$ due to a lack of data. For the remaining stocks, ${ }^{41}$ the SCRS recommendations advised the adoption of strict rules; the Commission did not follow those recommendations. For instance, although in its 2008 report the SCRS recommended that the TACs ${ }^{42}$ of bluefin tuna in the East Atlantic and the Mediterranean should not exceed 15.000 tons, the Commission set a TAC of 28.500 tons for the year 2008 .

The Commission thus makes a choice amongst the SCRS recommendations which seem, at first glance, all essential for biodiversity protection. Making such a choice thus marks the end of the scientific stage and the beginning of the political one; objectives shift and after the nature of the sought-after truth changes. The scientific truth (or truths) leads experts to recommend the most protective rule, the one which will allow achieving the scientific objective of stock restoration to sustainable levels, whatever the social and economic impact of the measures adopted to implement the rule. The 'legal truth' in international law does not lead decision-makers along the same path as the scientists. It leads them to find the rule which will be accepted by the highest number of states. This rule will certainly not be the most

\footnotetext{
37 'est préparatoire et non décisionnel': Yves Daudet, 'Les membres des commissions d'experts', supra note 19, at 99.

${ }^{38}$ On the autonomy of decision-making authorities vis-à-vis scientific bodiess, see Christine Noiville, $D u$ bon gouvernement des risques (Paris, PUF, 2003), at 68-77.

${ }^{39}$ The target species are the main species assessed by the SCRS: albacore, bigeye tuna, bluefin tuna, blue marlin, white marlin, sailfish tuna, skipjack tuna, yellowfin tuna and swordfish.

${ }^{40}$ Report of the Independent Performance Review of ICCAT, Madrid, 2009, at 3.

Available at : < http://www.iccat.int/Documents/Other/PERFORM_\%20REV_TRI_LINGUAL.pdf $>$ (visited 24 November 2009)

${ }^{41}$ Albacore in the North Atlantic, albacore in the South Atlantic, bluefin tuna in the West Atlantic, bluefin tuna in the East Atlantic and Mediterranean, blue marlin, white marlin and swordfish in the Mediterranean.

${ }^{42}$ Total Allowable Catches.
} 
ambitious one but its effectiveness potential will be higher. ${ }^{43}$ Thus, if scientific truth aims at maximum protection, the 'legal truth' rather looks toward optimum protection. The final decision will indeed be made with regard to the scientific knowledge the experts provided but it will also be modified once again depending on the social and economic interests of the actors involved. The decision-making body must balance the advantages and drawbacks of each measure put forward by the experts to work out what will be turned into a prescriptive rule and what is to remain a scientific statement. ${ }^{44}$ The diplomatic body thus operates a 'knowledge-shopping' to draw up socio-technical rules. It takes what it whishes from the submitted scientific data, or what it can reasonably accept because implementation in the social sphere is feasible. This data extracted from the scientific sphere because it is transposable into the social sphere will be an integral part of the final socio-technical rule. They will allow the decision-making organ to set the foundations for its decision and will also push the states to respect them. The diplomatic body thus becomes the judge of expertise since it arbitrates on whether the recommendations can be transferred into the social sphere.

Interaction between science and law seems to reach its climax here: experts transform their scientific knowledge to prepare its translation into the decision-making sphere, and decision-makers make perform a value judgement on the proposed scientific statements to determine which ones are actually transferable into the social sphere. Such transposition, if it does not run counter to an interaction between science and law, is a priori more incompatible with a possible interpenetration of the two fields while the socio-technical rule is really a hybrid rule. In fact, the use of the term 'transposition' only reflects the moving of scientific knowledge from one sphere to the other; it does not induce a possible transformation of the scientific knowledge which was produced. On the contrary, when the Commission adopts SCRS recommendations, it adopts them as is, which leads us to wonder if, to a certain extent, the scientific statement does not in itself hold some normative value.

\subsection{The adoption of a 'pre-law' by the diplomatic body}

When the Commission adopts SCRS recommendation, it merely transforms words into action through a vote and grants the scientific statement a legal status. But even before this transformation, scientific statements are already operational. When the Committee recommends that ' $[\mathrm{u}]$ ntil sufficiently more research has been conducted to reduce the high uncertainty in stock status evaluations for the southern Atlantic swordfish stock, the Committee recommends that annual catch should not exceed the provisionally estimated MSY

\footnotetext{
${ }^{43}$ This dichotomy between scientific truth and legal truth when using expertise has also been highlit in the case of jurisdictional expertise. The expert will try to provide exact scientific evidence based on current knowledge, whereas the judge's role is not to find the truth but to arbitrate a dispute, which does not automatically mean that one must know the scientific truth in order to arbitrate. Please see Cesare Romano, 'L'expertise en matière environnementale: experts pour qui ?', in French Society for International Law, Le droit international face aux enjeux environnementaux (Paris : Pedone, 2010), pp.181-187.

${ }^{44}$ According to Robert Castel, 'la législation se contente d'entériner, c'est-à-dire d'accepter en la traduisant sur un mode prescriptif, une production de savoir d'expertise' ('the law content itself with ratifying, that is with accepting while translating it according to a prescriptive mode, a production of expert knowledge'). See Robert Castel, 'Savoir d'expertise et production de normes', in François Chazel \&Jacques Commaille eds, Normes juridiques et régulation sociale (Paris, LGDJ, 1991), 177-188, at 185.
} 
(about 17,000 t), ${ }^{45}$ the socio-technical norm already exists. Experts already determined the threshold of risk which is acceptable to society, based on existing knowledge, and even included social components into their scientific statement. Depending on social and economic factors, experts defined some social needs and weighed them against environmental needs to produce what is a quasi socio-technical rule. This rule only lacks the legal force that will be granted through the vote of states. But when does the vote actually occur?

Within the SCRS, numerous scientists work as state representatives, which means that scientific expertise is admittedly performed by experts, but experts mandated by states. The norm thus set up is the result of a negotiation within a hybrid forum in which states, prior to the intervention of the diplomatic body, have already the opportunity to accept the rule. Through this process, doesn't the norm created then already have legal nature? Even if it seems difficult to consider that the SCRS reports contain rules with a legal weight equal to those that have been voted by the states through the diplomatic body, given the renegotiation taking place within this forum, it is all the same unreasonable to conceal the fact that states have already indirectly attributed a certain degree of legal value to this norm. It would undoubtedly be more suitable to make use of the gradations offered by international law (and the reports of expert commissions might be one) up to the compulsory stage resulting from state will' ${ }^{46}$ If this thought lays itself open to criticism, particularly from a Manichean point of view on international law, according to which there is a strict dichotomy between law and non-law, it still offers rich perspectives for the protection of fish resources, particularly in the framework of the cooperation between the ICCAT and the General Fisheries Council for the Mediterranean (GFCM).

The conservation and management of highly migratory fish (tuna and tuna-like species) in the Mediterranean come under the mandate of two organizations, the GFCM and the ICCAT. The ICCAT was created twenty years after the GFCM but from the onset, both organizations established spontaneous cooperation. The reasons for this are easy to understand. The overlapping of competences ineluctably led to dialogue in order to avoid reciprocal paralysis of the two systems and to ensure their efficiency. Yet, this cooperation was only informal. The ICCAT was created by the Rio de Janeiro Convention on the $14^{\text {th }}$ of May 1966 and has the legal status of an international organization with the legal competences which go along this status. ${ }^{47}$ The GFCM is a "semi-autonomous" institution which belongs to the FAO family of regional fisheries commissions, and thus cannot have the same

\footnotetext{
45 Report of the SCRS, Madrid, Spain, 29 September - 3 October 2008, at 140. Available at: $<$ http://www.iccat.int/Documents/BienRep/REP_EN_08-09_I_2.pdf> (visited 24 november 2009).

46 'Sans doute, conviendrait-il mieux, de la sorte, de profiter des gradations qu'offre le droit international (et les rapports des Commissions d'experts peuvent en être une) jusqu'à l'obligatoire résultant de la volonté des États': Daudet, 'Les membres des commissions d'experts', supra note 19, at 107.

47 The ICJ has clarified doubts on the legal capacity of international organizations as early as 1949: 'In the opinion of the Court, the Organization was intended to exercise and enjoy, and is in fact exercising and enjoying, functions and rights which can only be explained on the basis of the possession of a large measure of international personality and the capacity to operate upon an international plane. (...) It must be acknowledged that its Members, by entrusting certain functions to it, with the attendant duties and responsibilities, have clothed it with the competence required to enable those functions to be effectively discharged'. (Reparation for injuries suffered in the service of the United Nations, ICJ Reports (1949), at 179.). This reasoning is transferable to all international organizations that apply the principle of specialty.
} 
competences as the ICCAT. ${ }^{48}$ Cooperation between the ICCAT and the GFCM could hardly be achieved through a direct agreement between the two institutions. ${ }^{49}$

The ICCAT-GFCM cooperation operates on several levels, but what is of interest in the framework of the present study is that the ICCAT attends the GFCM annual general meetings as an observer and, as such, presents recommendations and attaches great importance to their adoption by the GFCM so as to harmonize their tuna management policies. The members of the ICCAT and of the GFCM are not the same. In adopting the recommendations the ICCAT submits, the meeting of states that are parties to the GFCM not only adopts a norm that it did not negotiate but also a norm that was firstly negotiated within the SCRS and then by other sovereign states within the ICCAT Commission. Thus, swordfish fishing in the Mediterranean Sea was banned from the $15^{\text {th }}$ of October to the $15^{\text {th }}$ of November 2008 by the 32nd session of the states party to the GFCM when this measure had been adopted in 2007 by the ICCAT ${ }^{50}$ and submitted in 2008 to the GFCM Commission. If this is not characteristic of an abandonment of the voluntarist logic, it still opens a very interesting door to international cooperation to protect biodiversity. Within the GFCM, states adopt socio-technical rules the negotiation process of which is entirely out of their control. The technical aspect of the rule was elaborated and then negotiated according to social needs identified within the scientific body of the ICCAT. This socio-technical norm was then renegotiated within the diplomatic body of the ICCAT which means that the GFCM, which automatically adopts these recommendations, did not take any part in the elaboration of the socio-technical rule and yet accepts its application within its sphere. In other words, the GFCM contents itself with giving a formal a legal nature to a pre-elaborated norm, in order to allow it to enter its scope too. This phenomenon reminds us of Peter Haas' theory on the influence of the 'epistemic community' in decision-making. ${ }^{51}$ The consensus operating within the scientific committee will lead to the adoption of a realistic socio-technical rule which will reinforce the cooperation not only within the forum where the expertised was commissioned but also between 'competing' institutions. In this way, competition is left aside in favour of a harmonization of applicable rules. Diplomatic bodies are thus served socio-technical rules on a silver platter, and rules which were after all drafted by the 'epistemic community'. More than a pre-law, expertise probably makes some law. This phenomenon reveals the weight of science in law but the weight not of some 'pure' science, but of a science adapted to decisional constraints.

\footnotetext{
${ }^{48}$ The GFCM in its 22nd session in October 1997 and the FAO Council in its 113th session in November 1997 amended the agreement creating the General Comission for Fisheries in the Mediterranean to give it the status of an autonomous UN organization by allowing it to manage its own budget. This amendment entered into force on the $29^{\text {th }}$ of April 2004 for the states which ratified it (only the United Kingdom, Egypt and Syria did not).

${ }^{49}$ An agreement has been in force between the ICCAT and the FAO since 1973, which organizes the cooperation between these two organizations. If this agreement surely facilitated the cooperation between the ICCAT and the GFCM, it did not necessarily trigger it.

50 'Recommendation by ICCAT on Mediterranean swordfish', Recommendation [07-01], adopted during the $20^{\text {th }}$ Regular Meeting of the Commission, Antalya, Turkey, November 9-18, 2007 and entered into force on the $5^{\text {th }}$ of June 2008.

${ }^{51}$ According to Peter Haas, an 'epistemic community' is defined as 'a network of professionals with recognized expertise and competence in a particular domain and an authoritative claim to policy-relevant knowledge within that domain or issue area'. See Peter Haas, 'Introduction: epistemic communities and international policy coordination', 46 International Organization (winter 1992) 1-35.
} 
Finally, the interaction between science and law are constant in the making of sociotechnical rules on fisheries conservation. The linear expertise system finds no illustration within the ICCAT because where science establishes facts, law intrudes, and where decisionmakers make law, scientists already paved the way. The role of decision-makers is reduced to choosing and validating the norms created by experts, whereas experts exceed the limits of their role in order to draft scientific assessments which include a part of juridical normativity. It would be tempting to talk about the despotism of science but it seems that its hegemony, if it is not consciously instrumentalized by decision-makers, it is at least the driving force of a political consensus for a joint resources management. Scientific data lays the foundation for legal rules and gives states the illusion of a certain legal security... A security which is all in all paradoxical given the scientific uncertainties socio-technical rules were built on. 